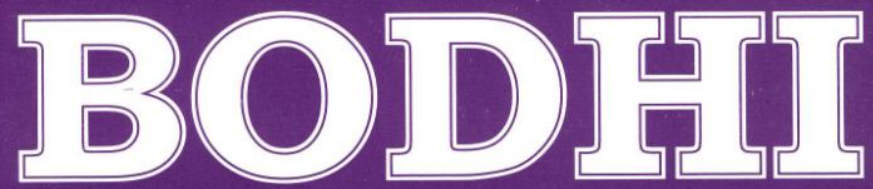

An Interdisciplinary Journal

ISSN: 2091-0479

Department of Languages and Mass Communication School of Arts

Kathmandu University

Bodhi, 4 (1), 168-190. ISSN 2091-0479. (C) 2010 Kathmandu University 


\section{Machinery of state control: History of cinema censor board in Nepal ${ }^{1}$}

- Harsha Man Maharjan

Inside film industry, film censor board is a small but important institution. In Nepal, this institution always works as the structure to fulfill the interest of the state. Sex, violence and politics are main reasons of cinema censorship but meaning and acceptance of these issues are changing in Nepal. This article argues that it is right time to rethink the work of the censor board. Instead of scissoring cinemas, it has to grade them.

\section{Introduction}

Cinema/Film Censor Board is a small entity of a film industry, and it is a global practice. However, who forms this entity differs among countries. For example, in Britain and the US, film industries have established this mechanism. But in countries like India and Nepal, the state has established the censor board and the board is basically the machinery of state control. It orders to scissor the scenes which it feels objectionable/harmful to the society and the state. It even denies certification to movies and dubs them banned if the whole cinema is assumed to be unsuitable for the state and society.

\footnotetext{
${ }^{1}$ This article is a longer version of what I published in Republica (Maharjan, 2010) . Here I have corrected some factual errors I did in newspaper article due to the lack of data. I am indebted to Shiva Regmi for providing information and documents I used in this study. Collection of Nepal Gazette available at Tribhuwan University Central Library became valuable for me. I thank members of this library. I also thank Kamal Prakash Malla, Chetan Karki, Yadav Kharel for talking with me.
} 
Many people have studied different aspects of Nepali film industry. And their focus is in larger issues like the beginning of Cinema in Nepal (Ajeet, 2007), overall film industry (Karki, 2002), and issues of Dalit in Nepali cinema (Subedi, 2006) etc. But there is no sole study on the history of film censor board in Nepal. We can find some studies on film censorship and censor board in India. One of them is Derek Bose's Bollywood Uncensored: What You Don't See on Screen and Why. It gives detailed information on which scenes of cinemas the board cut and reasons behind this (Bose, 2005). Next is Someswar Bhowmik's Cinema and Censorship: The Politics of Control in India, a Ph D dissertation on the history of Indian Censor Board published into a book. This book covers the activities of Indian censor board from British India to 2006 (Bhowmik. 2009). For this study he used archival documents related to the board and Indian film censorship from 1915 to 2006.

In Indian case historical documents like verdict of the board, reports of cinematograph committees, journals as well as bulletins from film industry are available. Bhowmik has used these materials for his study. In Nepal, we lack these kinds of archival materials. Nowhere can we find a systematic file related to verdicts of the censor board. So writing the history of censor board is a daunting task. We have to bank on people's short memory. And this kind of research has a limitation. Usually, people will hide information that makes them ashamed. Thus writing history only through interviews with people on film industry is not enough. To write this article I have used books, articles, news, reports, legal provision etc. on Nepali cinema.

\section{The Rana period}

We can't imagine a censor board in absence of the culture of watching cinema. Studies show that cinema entered in Nepal during the Rana period. Generally people think that Rana period was a dark age. In reality in that period few good things happened. Planned development started during that period. 
Many communication technologies like radio, cinema entered at that time. The concept of modernizing Nepal through education and science also started.

Yes, there were both good and bad Rana rulers. Some tried to control peoples' inalienable rights of expression. Few others like Dev Shamsher made arrangements for publishing Gorkhapatra. Critics can say he did this to propagate Rana ideology. I don't disagree with them. But Gorkhapatra gave opportunity to raise awareness for few things: education, health etc. It is also during Dev's premiership that general people got chance to watch cinema in 1901. We have some proofs for this. In his book Rana Nepal: An Insider's View, Pramod Shamshere Rana (1978) writes this: "For the first time in Nepal he (Dev Shamsher) exhibited silent movies pictures to the public at Tundikhel parade ground, for one week, free of charges" (p. 109). Author Madan Mani Dixit and historian Prushuttom Shamsher Rana attest Pramode Shamshere Rana's claim. Dev Shamsher remained in his office as prime minister for 115 days and his premiership ended in June 1901. According to Dixit (1999), Dev Shamsher made provision for screening movies related to agriculture and education for royal coteries and mid servants. Prushuttom Shumsher (2002) writes that during Dev Shamsher's period, general people got chance to watch silent bioscopes in the evening.

From narratives of the above two Ranas, we can prove that cinema had entered in Nepal for general people as early as 1901. What we can say from Dixit's narrative is Rana families and their servants were the first class of people to watch cinema in Nepal. That means some Ranas might have watched movies even before 1901. Cinema came into existence in 1895 in France. Within a year, Indians got chance to watch it. Five years later Nepali people got opportunity to watch silent movies.

In 1929, the Ranas could watch 10-15 cinemas a year in Judhha Shumsher's palace (Rana, 2001). Cinema had entered in Madan 
Mani Dixit's house in 1929. But general people could watch movies only when the Ranas arranged screening for them. But these screenings were irregular.

A permanent public cinema hall was established in Nepal for in the last days of the Rana period. When cinema watching became a habit the relatives of the Rana rulers, these people asked permission with the last Rana Prime minister Mohan Shumsher for operating cinema hall. Mohan could deny no one for permitting a person was to dissatisfying others. So Vijaya Shamsher, his son advised Mohan to operate a cinema hall owned by government and to use the hall's income in developing municipality. Thus, the government established the cinema hall called Kathmandu Cinema Hall on 26 November 1949. More often it used to show religious cinemas. People were eager to watch cinemas and watching cinema was a kind of donation to the municipality (Pandey, 1989). But the socalled untouchable was denied entry in the hall till 1951.

During the Rana period there was no censor board. But in global context this kind of entity had evolved in the early decades of twentieth century. Demand of censorship came in the pretext of obscenity and violence. The censor board had evolved in Britain, the US, India etc. In Britain, the British Board of Film Censors (BBFC) came into existence in 1912. It censored cinemas on the ground of politics, violence and absence. In the USA, in 1919 the National Board of Review of Motion Pictures and National association of the Motion Pictures Industry established thirteen points. The points are a list of scenes and topics the industry needed to avoid (French and Petley, 2007). Indian Cinematography Act 1918 made a provision for formal censor board during the British India. Before that censoring of cinema had worked in ad-hoc basis (Bhowmik, 2009). So, why did Ranas care nothing about the censor board? Generally Ranas used to get cinema from Calcutta, India and these films were already certified by British India censor board. And the Ranas trusted the British Indian Government. 
Cinema was an expensive medium. General people could not afford it. Some Ranas and people near to Ranas as the Dixit family could afford it. As screening of cinemas was in control of the Ranas, there was no need of establishing censor Board in that period.

\section{The Post-Rana period (1950-1960)}

The Rana regime ended in 1950 and democratic polity began. On 18 February 1951 the Rana-Congress Coalition government was formed under the premiership of Mohan Shumsher. And Bishweshwar Prasad Koirala became home minister of this cabinet. This government nationalized cinema in August 1951. At that time cinema was nationalized in global content for two reasons. First, governments wanted to reconstruct cinema after it collapsed in the world wars. The second was to control expression as USSR did it after 1917 (Terrou and Solal, 1951).

As a bid to nationalize cinema, the Nepali government formed a 7-member film censor board by publishing a notice with title Cinematograph in Nepal Gazette on 27 August 1951. The board which was under Home Ministry included five representatives from the government side and two from the private side. The board had to watch cinemas and certify them. Every member of the board got Rs. 10 for this. If anybody violated the rule the board could charge her/him Rs 1000 and confiscate the machinery (Nepal Sarkar, 1951a). This was a big amount at that time and must have worked as a deterrent. The cabinet decided to change the fee as it felt the rate unreasonable. So, on 1 October 1951 the cabinet set the fee to Rs. 5 for $16 \mathrm{~mm}$ cinema and Rs 10 for bigger than this (Nepal Sarkar, 1951b). On the very day, Nepal Gazette published the rules created by the meeting of the film censor board (Nepal Sarkar, 1951c ). Jagaran, a weekly magazine, published the full text of the guidelines (Pix no. 1 below). It contained eight points:

1. Do not pass cinema that promotes communal feeling and disturbs tranquility of the society. 
2. Do not pass cinema if it is obscene and vulgar (But if presentation is artistic it is not deemed obscene).

3. Do not pass cinema if it propagates superstition and checks modern and progressive ideology.

4. Do not pass cinema if it promotes feudalism, imperialism and regressive ideology.

5. If cinema needs to cut few scenes, do it if it does not hamper the story of cinema.

6. Do not pass cinema if its quality is poor that can damage audiences' eyes.

7. Besides above rules, the board can decide the fate of the cinema in different occasions.

8. Now on, while screening cinema, it must contain film number provided by the board in the beginning. (Nepal Sarkar, 1951 a, p.10-11, translation mine)

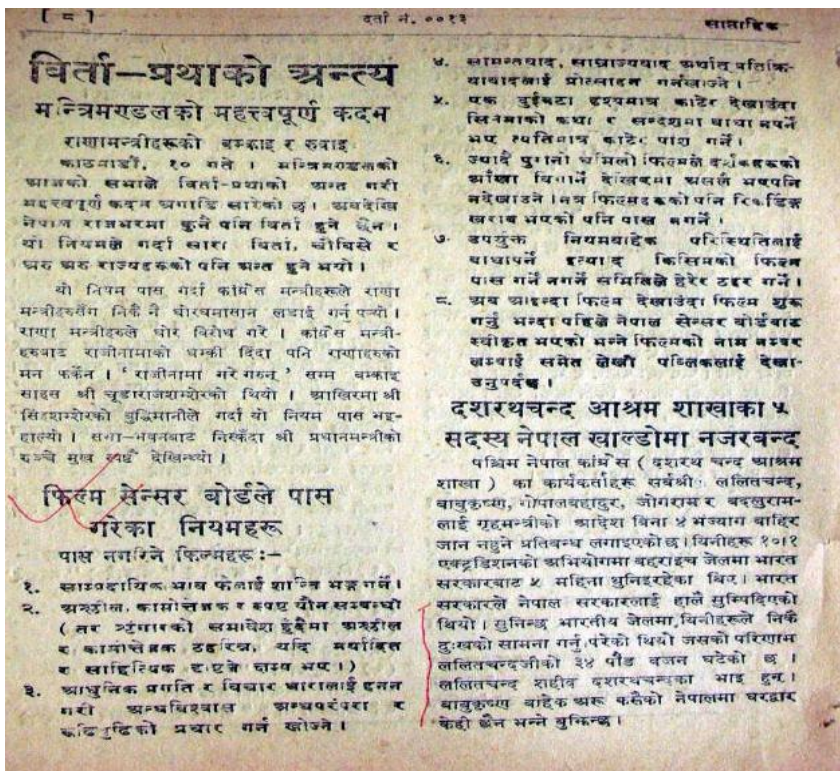

Pix no. 1. Rules of film Censor Board published in Jagaran (Jagaran, 1951, p. 8)

${ }^{2}$ I got this document from media historian Shiva Regmi, I thank him for this. 
Broadly we can see these rules in five categories: sex, crime, politics, management of cinema and safety of viewers. The first rule fits under crime, the second implies sex. The third and the fourth come under politics, the fifth, seventh and eight signify management of cinema, and the sixth rule fits under the safety of viewers. Yet few rules of this board were unclear, broad and open to various interpretations. For example what is the intention of the post-Rana state while using words like feudalism and imperialism? Aren't they vague? Actually this vagueness must have given chances to the state to misuse the rules. We can see these rules as the euphoria of the end of Rana period; now Nepal would tolerate no feudalism and imperialism. Though the sixth rule shows that the state took care of the safety of viewers by checking poor quality cinema, the fifth, the seventh and the eight prove that the main intention of the state was to manage the sources of information people were using. That's why we can say that the concept of film censor evolved in post 1950 period to suppress the sources of information of people. Till this period no cinema was made inside Nepal. So, the government did not form this board to certify Nepali cinema. It had only to certify foreign cinemas that were brought inside Nepal.

There must be another reason for establishing this board. The government must have become alarmed to get permissions from other people to open cinema hall in Kathmandu. Kathmandu Cinema Hall was the only cinema hall inside Nepal during the Rana period. In the post-1950 period, the monopoly of this hall was broken. New cinema halls appeared. According to media historian Shiva Regmi, these are new cinema halls that were established later -- Jaya Nepal Cinema Hall (1953), Moonlight (1953), Bishwa Jyoti (1953), Chalchitra (1954), Prabaha (1954) Shreehall (1955), Nawadurga (1956), Ranjana(1957), etc ${ }^{3}$. This must also have triggered the government to establish the censor board.

${ }^{3}$ It is based on an interview conducted with Regmi on 23 April 2010 


\section{The Panchayat period (1960-1990)}

The Panchayat government made feature films inside Nepal. The state made the film, Aama in 1964. In the early years of this period there was no act to govern production, distribution and exhibition of cinema. And the censor board was working by the notice published during democratic government of the post Rana period. This scenario changed in 1969. The government enforced the Motion Picture (Production, Exhibition and Distribution) Act, 1969 on 4 September 1969. Article 7 of this Act had made provision for a film censor board. It didn't say how many people would be in the board. Neither did it mention who these people would be. It gave authority to the government to form this board by appointing chair and members. The Act gave four criteria for certifying and not certifying movies:

a. Permit the said motion picture to exhibit publicly without prescribing any condition.

b. Permit to exhibit publicly subject to any alteration, modification or abiding by any other conditions and restrictions.

c. Permit prescribing the condition that the said motion picture shall be exhibited publicly for the adults above the age of sixteen years or

d. Refuse to give permission to the motion picture for public exhibition.

(Shree Panch Ko Sarkar, 1969, p. 62).

But the Film Censor Board must give "reasonable opportunity to the applicant to express his view prior to the decision. The board could modify scenes of cinema if it found that cinema undermined "His Majesty King or the royal family," jeopardized "the security, peace and order of the Kingdom of Nepal," harmed "the harmonious relation with the foreign states or the peoples of various castes or tribes," might "cause negative impact to the public interest or decent behavior or morality" or defamed "any person or contempt of court or incitement to any offence." 
The Act even authorized the government to stop "the motion picture already permitted by the Film to stop the exhibition of the motion picture" if government found them objectionable. The government could nominate its chair and members (Shree Panch Ko Sarkar, 1969). That means the government could overrule the verdict of the board. This Act also gave opportunity to people who were aggrieved by the decision of the board to appeal before the government within the thirty-five days of such decision.

Usually rules and regulations help in operating acts. The government enacted Film (Production, Exhibition and Distribution) Rules, 2027 v.s. on 3 August 1970. It gave power to establish censor boards in districts after publishing notice in Nepal Rajpatra. Now all members of the board could get Rs. 40 for certifying a movie (Shree panchko Sarkar, 1970).

In 1971, this board was shifted from Home Ministry to Ministry of Communication. It was done under the recommendations of National Communication Services Plan 1971. This plan which modernized different national media intuitions, purposed one representative each from Home Panchayat Ministry and Royal Nepal Film Corporation (RNFC) in the board (Shree panchko Sarkar, 1971) ${ }^{4}$. The government established RNFC to develop film industry in Nepal. During a seminar organized by RNFC in November 1972, participants had three suggestions related to the censor board. First, it requested the government to form philosophical guidance for censor board. Second, it urged the government to change the conditions for mandatory presence of some members of the board while certification. Instead, it proposed the provision for presence of majority of its members. It requested government to reduce the fee for certification in other places than Kathmandu (RNFC, 1972).

\footnotetext{
${ }^{4}$ For information about the making of this plan, pls see maharjan 2009.
} 
On July 5, 1976, the government scraped Film (Production, Exhibition and Distribution) Rules, 2027 v.s. It enacted Film (Production, Exhibition and Distribution) Regulations, 2033 v.s. It just increased the fee to Rs. 100 and gave full authority to Zonal Commissioner and CDO to manage the board (Shree Panch Ko Sarkar, 1976). That means the government paid no attention to the suggestions of the seminar. According to Kamal Prakash Malla, who remained in this board for two years, the Censor board started to function in Nepal in 1976 only and before that Nepal used the certification of the Central Board of Film Censor of India ${ }^{5}$. For example in the VCD of Maitighar available at market, there is the certification of Indian censor board (Pls see pix no. 2), and there is the certification of Nepali censor board in Kusume Rumal (Pls see pix no. 3). Chetan Karki, who worked in Department of Information and later in Royal Nepal Film Corporation informed that in the Panchayat period Nepali cinemas were printed in India and there was a need for screening cinemas inside Indian places like Darjeeling, Sikkim etc. To give permission to screen them in India, Nepali cinemas needed a certification of Indian censor board. Thus most of the cinemas got Indian certificates and Nepali censor board approved them.

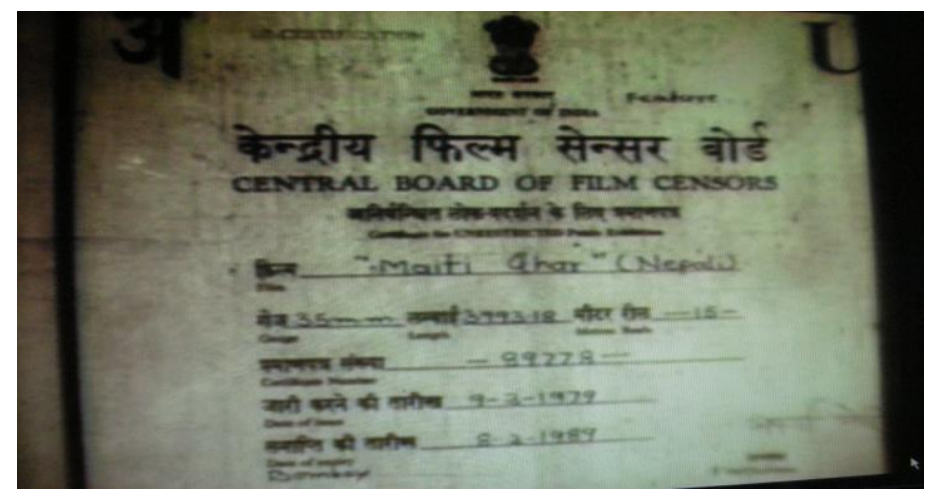

\footnotetext{
${ }^{5}$ It is based on email I received from Malla on 23 April 2010.

${ }^{6}$ It is based on an interview I did with Karki on telephone on 23 April 2010.
} 
Pix 2. The certification for Maitighar by the Central Board of Film Censors, India

In 28 August 1989, Nepali government enacted another regulation and scraped 2027 v.s. regulation. It authorized the government to form one or more censor boards of 7 member censor board (Shree panch Ko Sarkar, 1989). The regulation did not say who these members would be. So we can guess that all members must be appointees of government. Like the previous regulation, it did not contain the suggestions of the seminar.

In the Panchayat period, all Nepali film makers knew what was objectionable to government and the board-Foreign policy, socalled social harmony, monarchy etc. These film makers experienced few hassles from censor board. But even if the censor board had asked some to cut few scenes, it never came in media. And public might know nothing about this. So it is difficult to find many examples of rude treatment of the board in Panchayat peiod. However, there were few cinemas which felt hassles in the censor board. According to Gopaljee Nepali, Censor board objected the use of helicopter with green color by gangster in a movie called Jeevan Jyoti. A person from Royal Nepal Army opposed this, saying that the color of helicopter was similar to the helicopter used by army and people could infer that army was enmeshed in smuggling. Later the board passed the cinema. ${ }^{7}$ The Censor board objected cinema Hami Ek Haun, a joint venture of Nepal and Pakistan. It was dubbed in Nepali. It had shown act of smuggling from a policeperson and the members of the board could show no courage to pass it. At last people from palace, Head of Police and army general watched and approved it (Kamana Pratinidhi, 2005). But there must be many foreign movies which the board banned. Yadav Kharel, who was General Manager of RNFC and a member of the board in 1970s has informed that the board banned an Indian movie which was critical to monarchy. Here he is not referring to Manoj Kumar's Kranti. The banning of Kranti by

\footnotetext{
${ }^{7}$ It is based on an interview I did with Nepali on 19 September 2009.
} 
the board is well known fact. In 1981, Manoj Kumar, Indian film maker and actor made a movie called Kranti about Indian struggle for independence from British government. Panchayat government banned this cinema. But it could not stop people from watching. This film was never shown at halls but people watched it at home through video player. According anthropologist Mark Lietchy, that ban helped in secret screening of Kranti, and some video parlors charged upto Rs 2500 for lending a cassette for three hour (Lietchy, 2003, p. 157).

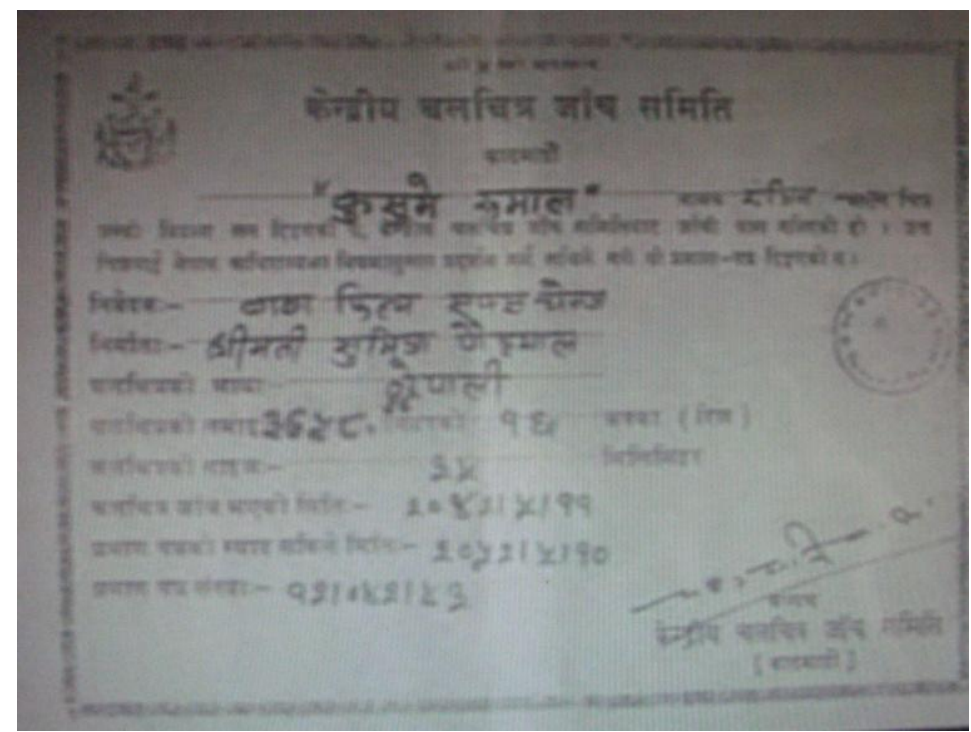

Pix 3. Certification of Nepali censor board in Kusume Rumal

Kamal Malla's words tell which kind of cinemas the board censored:

Some films were rejected because they were likely to incite civil disorder, others because they were against religious harmony, yet others because of exposure of a great part of female torso. The cinema halls were careful not to submit explicit movies with subversive themes or plot likely to destabilize the established moral or political order. No one approved Haward Fast's (Stanley 
Kubrick's) Spartacus nor Fellini's La Dulce Vita. Even Robin Hood was a suspect then. No Nepali film director ventured then to show a heroine wearing a Hare Ram Hare Krishna lungi or gamcha!

Peter J. Karthak has describes an interesting scene from the censor board on a context when Uttam Kunwar, one of the powerful members of the board had taken him to the board:

A Hindi film was screened for a surgical operation. Presently a wedding barat scene unfurled with the decked-up bridegroom hero of the movie astride an Arabian stallion arriving to claim the actress bride. The gala scene was synched with a plucky 6/8-beat song which had the words "raja" and "ghoda" in it. Uttam Dai stood up and decreed: "Remove the entire song. It's unacceptable in Nepal. Horse and King don't go together here." The other members intoned: Nepal's monarch rides elephants, flies in his super Puma, drives his Jaguar and is transported in his stately Daimler Benz. Cut! (Kathak, 2007, p. 5)

This shows the mentality of the censor board members. People who had says in the board seemed to be hell-bent to serve the palace's interest. And this is not limited to the Panchayat government alone. Every state tries to fulfill its agenda through censor boards.

\section{Post-Panchayat period (1990-2010)}

Many film makers might have thought that mentality of the film censor board would change after the end of Panchayat system. But it did not. On 20 November 1991, the democratic government amended Motion Picture (Production, Exhibition and Distribution) Act, 1969 (Shree Panch Ko Sarkar, 1991). But it said nothing about the censor board. And there were no new rules related to cinema till 2000 . 
On 19 June 2000 the government enacted Film (Production, Exhibition and Distribution) Rules, 2000. This rule made the provision of a seven member board. These members were Joint secretary of Ministry of Information and Communication, representative of Home ministry, representative of culture, tourism and Aviation ministry, three people from the film sector including one woman, and an under secretary from Ministry of Information and Communication. It authorized two types of censor board in Nepal: central and local. The Central board would be based in Kathmandu, and the local at every district. Getting certification from the central was enough to screen a cinema in any places inside Nepal (Shree Panch ko Sarkar, 2000).

This rule was amended for the first time on 14 Februry 2002. It made provision of 5 member regional censor boards at Biratnagar, Pokhara, Nepalgunj and Dangadi (Shree Panch ko Sarkar 2002). The government amended this regulation for the second time on 22 September 2003. Now, if the board had given Adult certificate, cinema producers and exhibitors needed to include this information in promotion materials. This amendment made mandatory to show the certificate of the board while exhibiting the cinema, and prohibited to add or cut scene from a certified cinema. The government amended this rule for the third time on 24 September 2007. But the amendment was unrelated to the censor board. The rule was amended for the fourth time on 11 January 2010. This amendment added a member from Film Development Board in the censor board. It also made provision for four categories- $\mathrm{U}$ or suitable for all, PG or need parental guidance, $\mathrm{S}$ or for special profession and A or for audience above 16. Before this, there were only two categories: $\mathrm{U}$ and A. Present certification is similar to that of India. It also made provision of Rs. 3,000 as fee for Nepali cinema of 1 hour, advertisements, and cinema on languages of Adhivasi and Janjati; Rs.5,000 for cinema from Nepal which is longer than 1 hour as fee and Rs. 15,000 for foreign cinemas as fee to certify cinema (Nepal Sarkar, 2010). 
In pix 4 there is censor board's certification for Indian cinema phoonk-2.

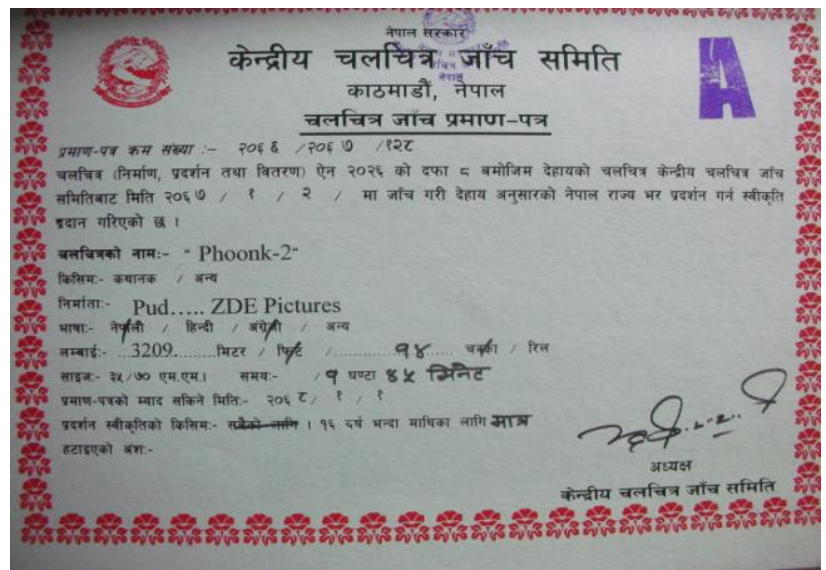

Pix 4. Censor board's certification of phoonk-2.

In a democratic government, media are comparatively more independent than in an authoritarian political system like Panchayat and there was media hype when the board tried to censor cinemas. So, we have many examples of Nepali movies that got hassles from the censor board. Here I am discussing a few well-known examples related to Aago, Ahankar, Das gajja and Dasdhunga. In February 2000, the censor board objected few scenes of Aago, a movie by Narayan Puri, related to the Maoist movement. At that time the Nepali Congress Party was ruling the country and the Maoist movement was on the peak. The movie did not refer directly to the movement. However, the board accused Puri of propagating Maoist ideology and denied certification. According to a report published in Kamana magazine, the board banned this cinema for a long time. The board asked Puri to reshoot the movie and show the guerrillas in negative way. But academics opposed the board's behaviour. Leftist intellectual Hari Govinda Luintel asked the government to counter Aago instead of censoring it (Kamana Pratinidhi, 2005). At last after 11 months, the censor board certified it when the director accepted to mould the story as the board 
wished. And the guerrillas surrender before government at the end the film (Bhattarai, 2008).

After April 2006, Puri wanted to add deleted scenes in the cinema but the board had lost those scenes and he had to reshoot those scenes. He also added two revolutionary songs in the cinema (Sarkar, 2007). Now the VCD of this cinema is available at market and on the cover of Aago's VCD, it is written that this film was banned (see pix 5).

The demand for a grading system came from Nepali film industry in 2007, instead of a censoring system. This demand became vocal when the board tried to censor Dinesh Karki's cinema, Ahankar. Some even asked to do away with the board. At that time CPN (Maoist) was in the government. On 13 March 2007, the censor board objected Ahankar. The board asked Karki to cut scenes of assaults from both Madheshi and Pahadi communities, gory fight between two communities etc. There was hue and cry related to the cinema in media. Narayan Prasad Regmi was the chair of censor board at that time. He opined in a report of puiblished in Himal Khabar Patrika that this cinema would definitely evoke the feeling of hatred between Madhesi and Pahadi (Shrestha, 2007). And at last by cutting few scenes, the board approved it on June 2007 (Nepal Samacharpatra, 2007).

During the Ahankar row, film industry criticized the board for killing creativity. Nabin Subba, director of Numafung asked for doing away with the censor board in an interview published in Tarun, a Nepali weekly. He added that Nepal had to go for rating system (Tarun, 2007). Similarly, film journalist Deependra Lama requested the government to quit the game of scissoring and start rating (Lama, 2007). K. P. Pathak even opined to scrap the board and argued that if there was no prior censorship in other media why we needed it only for cinema and the censor board was only curbing their creativity. If the government couldn't scrap it, he requested, the government would have to start grading system (Baraili, 2007). 


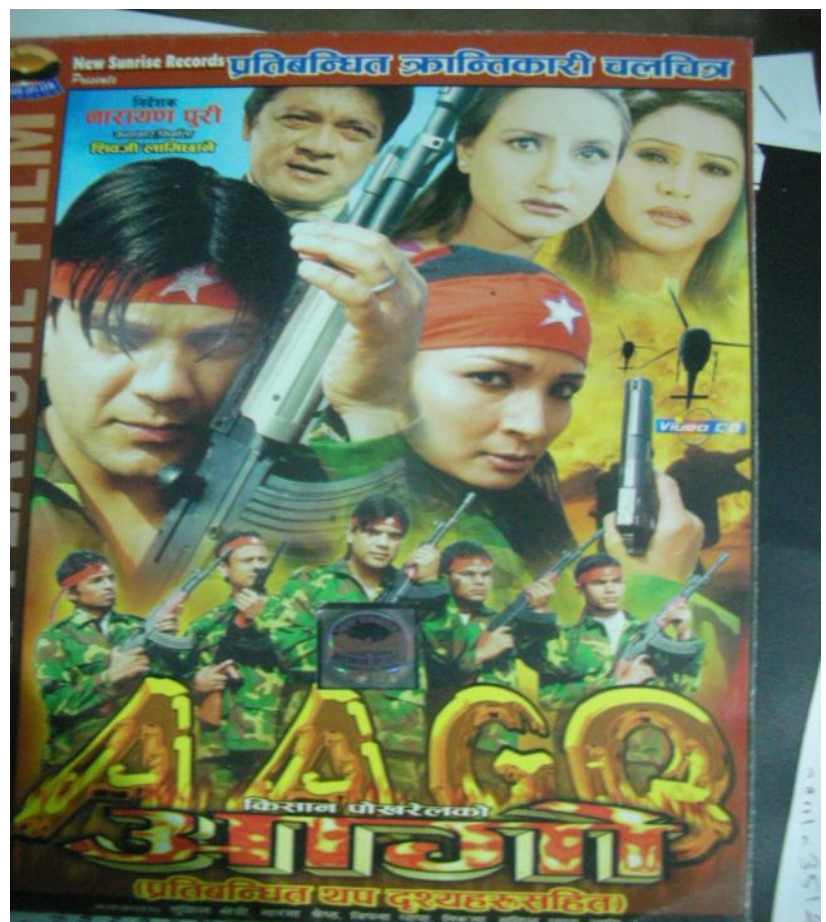

Pix 5. Cover of Aago's VCD.

Even after this, two cinemas Dasdhunga and Dasgajja experienced hassles from the board in early months of 2010. Dasdhunga is a feature film related to killing of two CPN-UML leaders: Madan Bhandari and Jib Raj Aashrit in a Jeep "accident" generally known as Dasdhunga Incident. How that "accident" happened is still a mystery. Many people believe that Amar Lama, the driver who was driving the jeep, intentionally faked an accident and killed them. But Lama had presented that incident as his negligence in his memoir (Lama, 1996). Manoj Pundit, the director of Dasdhunga, states he made this movie from existing documents - reports of commissions, memoir - about the incident. Earlier the censor board asked Manoj to scissor few scenes. After deliberation for one month, he accepted to bip three names - Madav Kumar Nepal, KP Sharma Oli and Dr Bharat Pradhan - from the 
cinema. In the movie during the interrogation with Amar Lama these names come ${ }^{8}$. This board passed this cinema on 24 February 2010 (Nagarik, 2010 a). Mahendra Guragain, chair of the board says, "We can't defame others. We don't know the reality of the incident. So, we asked to mute this name. We want to keep these people's honour. But people could figure out these people's names even if we have muted them." Dasdhunga is a political thriller related to the incident, so I think the board had no right to mute this name. In cinema, the board has bipped other terms like Indian Embassy, American Embassy, Bishwobandu Sharma etc.

Dasgajja is about the border issues like border encroachment, looting, intimidation from Indians at border area. The director of this cinema had experienced hassles and intimidation from different people while shooting the cinema. Its producer Nawal Khadka had informed the media that the censor board had demanded scissoring 10 scenes and dialogues of the movie, and if he had accepted the board's demand, Dasgajja would have become a movie of 10 minutes (Nagarik, 2010 b). Manoj Pandit thinks that film makers have right to criticize brutalities from Indian side in Nepal and India border area but the censor board fears that it jeopardizes the cordial relation between Nepal and India ${ }^{9}$. Mahendra Guragain, chair of the board, has informed that the board has no qualm on the criticism of looting, raping by Indians; what it objects is its presentation. According to him, the film presents facts unrealistically. It deliberatively presents facts provocatively ${ }^{10}$.

Nepali censor board is the state machinery to fulfill state's interest in cinema. But Guragai told that censor board only rates movies in Nepal. Yet he is showing parental attitude by saying that all film makers want to make cinemas with a Universal certificate. And he always endeavors to make cinema $U$ by cutting gory and sensual scenes. So his saying that the censor

\footnotetext{
${ }^{8}$ It is based on an interview I did with Pandit on 2 April 2010.

${ }^{9}$ It is based on an interview I did with Pandt on 2 April 2010.

${ }^{10}$ It is bases on an interview I did with Guragain on 12 April 2010.
} 
board is a rating body is untrue. The board has no right to certify X-rated movies as adult. These movies are illegal in Nepal. But in Nepali media, there is a hue and cry that the board has certified Palpalma as Adult category. Guragai informs that Palpalma got this category as there was no provision of certifying PG at that time. But Navin Subba had opined in media that the board must allow making adult movies in Nepal (Tarun, 2007). For that the government must amend the laws related to production, distribution and exhibition of cinema. This law denies adult's right to watch and see adult cinemas.

There is a row going on between the censor board and Nepali film industry. There are three schools thought about reforming the censor board. Some say cinema people must handle this job and everything will be all right. Others say the board should be an autonomous body. Some say we have to do away with the board. But Manoj Pandit goes for reform in the censor board. He thinks that we need a censor board but the board must redefine the meaning of violence and nudity. ${ }^{11}$ I think now time has come; we must go for rating in real sense. The board has to only certify movies. It has to renounce the parental attitude.

It is interesting that Dasdunga experienced hassles during the government of the Communist Party of Nepal (UML). The board was hell-bent to bip names of the Prime Minister and other leaders.

\section{Conclusion}

Even in Nepal censor board is a state machinery to control people's right to know though representatives of the board may argue that they gave priority to people's welfare. The examples of Aago, Dasgajja, and Ahankar show that in the name of public welfare the board has always been giving priority to

\footnotetext{
${ }^{11}$ It is based on views presented by Pandit on 15 July 2010 during a media discussion, Creative Cinema and Cinema Censorship in Nepal on censor board at Martin Chautari..
} 
state's interest. Now the time has come the state must change its attitude. It should show generosity. The board should mandate only to certify not scissor cinema.

We must remember that people's understanding and acceptance of sex and violence are changing. Flow and contra-flow of ideas, goods etc. have shattered our walls of tradition and values. The board must acknowledge this. Cinema is a creation and the board should check creativity of no cinema in the altar of public welfare. The censor board is the result of early $20^{\text {th }}$ century state mentality when the state used to see cinema as powerful medium and the general people as powerless. Studies have shown that audiences are active and can decide what is good for them. Instead of censoring the cinemas, the board has to literate people about cinema. It has to inform people about the process and reasons of cinema certification. The state should only facilitate cinema industry, not muzzle it.

The scope of this study is small. I have just briefly sketched the history of censor board. However, I think it fairly opens roads to further investigations on the topic. Researchers can attempt an in-depth history of each three periods or on the politics of political appointments in the board.

\section{Reference}

Ajeet, A. (2007). Nepalma chalchitra ko arambha (Beginning of cinema in Nepal). Media Adhyayan, 2, 35-74.

Baraili, S. (2007, August 18). Chalchitra Censor Board Kharej garnuparchha (Film Censor Board should be scrapped). Sanghu, p.6.

Bhattarai, D. (2008). Samajik rupantaranma Nepali chalchitrako yogdan (Contribution of Nepali cinema in social transformation). Chalachitra Manch, 3 (3), 70-80.

Bose, D. (2005). Bollywood uncensored: What you don't see on screen and why. New Delhi: Rupa.

Chauhan, R.S. (1971). The political development in Nepal 1950-1970. New Delhi: Associated Publishing House. 
Dixit, M. M. (1999). Anandamaya aakash (Comfortable sky). Kathmandu: Gyangun Sahitya Prakashan.

French, P., and Petley, J. (2007). Censoring the image. Calcutta: Seagull Books.

Jagaran. (1951). Film Censor Boardle Pass Gareka Niyamharu (Rules Passed by Film Censor Board). 1(31-32), 8.

Kamana Pratinidhi. (2005). Maobadi ko nam ma chalachitra Aago pratibandit (Cinema Aago Banned in the Name of Maoist). Kamana, 16 (5), 28-30.

Kantipur. (2005, September 25). Chalchitra pani pratibandit (Cinema also banned). p. 3.

Karki, C. (2002). Nepali film industry: Growth and development. In P. Khrael (Ed.), Sight, sound and pulse (pp.77-126). Kathmandu: Nepal Press Institute.

Karthak, P. J. (2007, June 17). Nepali censorship: Just messing around. The Kathmandu Post, p.3 .

Lama, A. (1996). Dasdhunga durghatnako darpan. Kathmandu: New Tribeni.

Lama, D. (2007, April 29). Kainchiko khel! (Game of scissors!). Nepal, 52-53.

Lietchy, M. (2008). The social practice of cinema and video viewing in Kathmandu. In Suitably modern: Making middle-class culture in Kathmandu (pp.151-182). Kathmandu: Martin Chautari.

Maharjan, H. M. (2009). Panchayati shasanma 'bikas ko lagi sanchar' awadharana ko rajniti (The politics of the concept, "communications for development" in the panchayat period ). Media Adhyayan, 4, 113-148.

Maharjan, H. M. (2010, April 16). Snip this, clip that: The politics of Nepal's Censor Board. Republica, p. 10.

Nagarik. (2010a, Febraury 25). Pass bhayo Dasdhunga (Dasdhunga is Passed). p. 12.

Nagarik. (2010b, February 24). Dasgajja lai Censorko adchan (Hassles of Censor to Dasgajja ), p. 12.

Nepal Samacharpatra. (2007, June 25). Ahankar Censor Boardbata mukta (Ahankar passed from Censor Board), p. 3 . 
Nepal Sarkar. (1951a, August 27). Suchana: Cinematograph (Notice: Cinematograph). Nepal Gazette, pp. 1-2.

Nepal Sarkar. (1951b, October 1). Suchana (Notice). Nepal Gazette, p. 5.

Nepal Sarkar. (1951c, October 1). Suchana (Notice). Nepal Gazette, pp.10-11.

Nepal Sarkar. (2010, January 11). Chalchitra (nirman pradarshan tatha bitaran) niyamawali, 2057 v.s. [Motion picture (production, exhibition and distribution) rule, 2000]. Nepal Rajpatra, 1-36.

Pandey, B. B. (1989). Tes bakhatko Nepal bhag char (Nepal at that Time - Volume 4). Kathmandu: Author himself.

Rana, H S. (2001). General Nara Shumsher Jang Bahadur Rana ko jivani (Life of General Nara Shumsher Jang Bahadur Rana). Kathmandu: Rani Aaishowri Rajya Laxmi Devi Rana.

Rana, P. S. (1978). Rana Nepal: An insider's view. Kathmandu: R.S. Rana.

Rana, P. S. (2002). Shree Tinharuko tathya britanta Bhag 2 (Facts of Rana Prime Ministers). Kathmandu: Vidhyarthi Pustak Bhandar.

RNFC. (1972). Nepalma chalchitraa pradarshanka samsya ra sambhabit samadhan gosthi (Seminar on problems of cinema exhibition and possible remedies). Kathmandu: Shahi Nepal Chalchitra Sasthan.

Sarkar, S. (2007, February 1 ). Free of censors: Nepal cinema breathes. Retrieved October 26, 2010, from http://news.boloji.com/200702/01318.htm.

Shree Panch Ko Sarkar. (1969, September 19). Chalchitra (Nirman Pradarshan tatha Bitaran) ain, 2026 v.s.( Motion picture (production, exhibition and distribution) Act, 1969). Nepal Rajpatra, 59-63.

Shree Panch Ko Sarkar. (1970, September 3). Chalchitra (nirman pradarshan tatha bitaran) niyamharu, 2027 v.s. ( Motion picture (production, exhibition and distribution) Rules, 1970 ). Nepal Rajpatra, 47-56. 
Shree Panch Ko Sarkar. (1971). Rastriya sanchar sewa yojana (National Communications Services Plan). Publisher not mentioned.

Shree Panch Ko Sarkar. (1976, July 5). Chalchitra (nirman pradarshan tatha bitaran) niyamawali , 2033 v.s. (Motion picture (production, exhibition and distribution) rule, 1976 ). Nepal Rajpatra. 1-16.

Shree Panch Ko Sarkar. (1989, August 28). Chalchitra (nirman pradarshan tatha bitaran) niyamawali, 2046 v.s .(Motion picture (production, exhibition and distribution) rule, 1989 ). Nepal Rajpatra,1-21.

Shree Panch Ko Sarkar. (1991, November 20). Chalchitra (nirman pradarshan tatha bitaran) samsodhan ain , 2048 v.s. (Motion picture (production, exhibition and distribution) Amendmant Act, 1991). Nepal Rajpatra, $1-4$.

Shree Panch Ko Sarkar. (2000, June 19). Chalchitra (nirman pradarshan tatha bitaran) niyamawali , 2057 v.s.(Motion picture (production, exhibition and distribution) rule, 2000). Nepal Rajpatra, 1-23.

Shree Panch Ko Sarkar. (2002, February 14). Chalchitra (nirman pradarshan tatha bitaran) (pahilo samsodhan) niyamawali , 2057 v.s. (Motion picture (production, exhibition and distribution) (First Amendment) rule, 2002). Nepal Rajpatra, 1-7.

Shrestha, D. K. (2007, May 30). Censor ko Bakheda (Hassles from the Censor). Himal Kharbar Patrika, 17 (4), $58-59$.

Subedi, A. (2006). Pardama dalitko chitran. Rupantaran, 3, 1938.

Tarun. (2007, June 14). 'Blue ilm' pani banauna paunuparchha. p. 6.

Terrou, F., and Lucien, S. (1951). Legislation for press, film and radio. Paris: UNESCO.

Mr. Maharjan is a researcher at Martin Chautari, Kathmandu. 